\title{
MULTIMODAL IMAGING IN PATIENTS WITH MULTIFOCAL CHOROIDITIS WITH OUTER RETINAL/CHORIOCAPILLARIS-BASED PATHOLOGY
}

\author{
Sonja Cekić1, Predrag Jovanović1,2, Ivan Jovanović2, Gordana Stanković-Babić1, \\ Dijana Risimić ${ }^{3}$
}

\begin{abstract}
The purpose of this study was to present different multimodal imaging technics in patients with multifocal choroiditis, punctate inner choroidopathy (PIC), birdshot chorioretinopathy (BCR), acute posterior multifocal placid pigment epitheliopathy (AMPPE), multiple evanescent white dot syndrome (MEWDS) and serpinginous choroiditis (SPC) and to estimate their diagnostic and prognostic value.

The study was performed at the Clinic for Eye Disease, Clinical Centre Niš, Serbia. During the period of six years, ten patients with diagnosed multifocal chorioretinitis were examined. Standard ophthalmological examination in all patients included: visual acuity evaluation, slit lamp biomicroscopy, applanation tonometry, indirect ophthalmoscopy, photodocumentation and fluorescein angiography, optical coherence tomography (OCT) and ultrasonography in indicated cases. Standard laboratory examination, immunological examination and HLA typing were performed as well.

Visual acuity was well preserved in all cases except in SPC. The disease was bilateral, in cases of SPC, AMPPE and PIC, and recurrence was present in cases of BCR and PIC. SPC and PIC were characterized by chronic evolution.

The common features of all presented cases of multifocal choroiditis entities were: minimal lesions at the initial stage of disease, multifocal or white yellow multiple lesions, during the progression of disease and consequent degeneration of retinal tissue and choroid proven by OCT and FA.

OCT is important for diagnose, differential diagnose and follow-up.

The obtained results are comparable with the existing studies that follow individual response variability, which has not yet been fully elucidated.
\end{abstract}

Acta Medica Medianae 2019;58(3):85-92.

Key words: chorioretinitis, diagnosis, imaging

\footnotetext{
${ }^{1}$ University of Niš, Faculty of Medicine, Clinic for Eye Diseases, Niš, Serbia

${ }^{2}$ University of Niš, Faculty of Medicine, Department for Anatomy and Clinical Anatomy, Niš, Serbia

${ }^{3}$ University of Belgrade, Faculty of Medicine, Clinic for Eye

Diseases, Clinic Center Serbia, Belgrade, Serbia
}

Contact: Sonja Cekić

Blvd dr Zoran Djindjić 48, 18000 Niš, Serbia

E-mail: sonjaziv@yahoo.com

\section{Introduction}

Multifocal chorioretinitis presents a group of rare disorders which primary pathologic process oc- curs at or near the level of retinal pigment epithelium (RPE) with or without photoreceptor outer segment and choriocapillaris involvement $(1,2,3)$. The pathophysiology presumes either vasculitic obstruction of the choriocapillaris with secondary infarction of the overlying RPE or, possible, immunologic response on RPE itself $(5,6,7)$. Many clinical features of these individual entities overlap, causing confusion $(8,9)$.

The aim of this study was to present different multimodal imaging technics such as, color fundus photography (FF), fluorescein angiography (FA), high definition ocular tomography HD OCT, ultrasonography in patients with multifocal choroiditis with outer retinal/choroidal based pathology-punctate inner choroidopathy (PIC), birdshot chorioretinopathy (BCR), acute posterior multifocal placid pigment epitheliopathy (AMPPE), multiple evanescent white dot syndrome (MEWDS) and serpinginous choroiditis (SPC) and to estimate their diagnostic and prognostic value. 


\section{Materials and methods}

During the period of six years, ten patients were diagnosed with multifocal choroiditis at the Clinic for Eye Disease, Clinical Center Niš. All patients gave standard written consent for all diagnostic procedures before the examination. Standard ophthalmological examination was performed in all patients: visual acuity, slit lamp biomicroscopy, applanation tonometry, indirect ophthalmoscopy, photodocumentation and fluorescein angiography (FA) (Carl Zeiss Digital Fundus Camera Visucam Lite), high definition, standard domain, optical coherence tomography (SD OCT Cirrus and RTVue 100) and ultrasonography B scan (USG Tomey) in indicated cases. The imaging methods, FA and SD OCT were done at the same condition and repeated during the treatment of disease. Standard laboratory examination, immunological examination and HLA typing were performed as well.

\section{Results}

Of 20 eyes examined during our study, 6 were diagnosed with AMPPE, 2 MEWDS, 4 PIC, 4

SCP and 1 BCR. Clinical and multimodal imaging results of examined patients are presented in Table 1. and Figures 1 to 6.

In case with PIC, acute lesions appeared as nodular collections under the retinal pigment epithelium, and presented as solid inflammatory retinal pigment detachment (PED) on OCT (Figure 1). These solid PED appeared to be ruptured leading to inflammatory infiltration of the subretinal space and outer retina, often with a widespread loss of the outer retinal architecture beyond the area of the inflammatory exudate. During the treatment with corticosteroids, in patients with $\mathrm{PIC}$, rapid regression of PED was noted, with a slower resolution of the abnormalities of outer retinal architecture. FA revealed more lesions that appeared as early hyperfluorescent lesions and late staining (Figure 1).

Anterior segment examination presented with mild inflammation, and mild vitritis in patients with BCR (Figure 2) (Table 1). On OCT focal disruption of the photoreceptors, inner and outer (IS/OS) focal or generalized were present (Figure 3). In macula, cystoid macular edema could be diagnosed. FA revealed prolonged arteriovenous transit time, optic disc hyperfluorescence, and vascular leaking (Figure 3). The delay of transit time is a phenomenon known as "quenching" and is pathognomonic for BCR.

Diagnosis of AMPPE was established in 3 patients and clinical signs were present in both eyes in different stages of disease (Table 1). On OCT hyperreflectivity of the outer retinal layers, inflammatory PED with presence of inflammatory cells were present (Figure 4). As the lesions resolved, hyperreflectivity of outer layer decreased. The IS/OS disruption, and atrophy of RPE can persist (Figure 4). FA demonstrated lesions with early hypofluorescence followed by the subsequent hyperfluorescence in the late venous phase (Figure4).

Table 1. Clinical and multimodal imaging findings in MPC

\begin{tabular}{|c|c|c|c|c|c|}
\hline Entity & Birdshot & AMPPE & SPC & PIC & MEWDS \\
\hline $\begin{array}{l}\text { Anterior } \\
\text { segment }\end{array}$ & $\begin{array}{c}\text { Without } \\
\text { inflammation }\end{array}$ & $\begin{array}{c}\text { Without } \\
\text { inflammation }\end{array}$ & $\begin{array}{l}\text { With mild cellular } \\
\text { elements }\end{array}$ & $\begin{array}{c}\text { Without } \\
\text { inflammation }\end{array}$ & $\begin{array}{c}\text { Without } \\
\text { inflammation }\end{array}$ \\
\hline $\begin{array}{l}\text { Posterior } \\
\text { segment }\end{array}$ & $\begin{array}{c}\text { Vitritis, } \\
\text { creamy yellow, } \\
\text { oval, diameter } 1 / 4 \\
\text { to } 1 \text { disc diameter } \\
\text { subretinal } \\
\text { infiltrates } \\
\text { from optic disc to } \\
\text { periphery }\end{array}$ & $\begin{array}{l}\text { Vitritis } \\
\text { white or creamy } \\
\text { yellow placoid } \\
\text { lesions/differ } \\
\text { during phase }\end{array}$ & $\begin{array}{c}\text { Vitritis } \\
\text { creamy yellow } \\
\text { subretinal } \\
\text { infiltrates } \\
\text { intermaculopapilla } \\
\text { ry and macula } \\
\text { and progress to } \\
\text { periphery }\end{array}$ & $\begin{array}{l}\text { Small, well } \\
\text { defined yellow } \\
\text { white lesions } \\
\text { CNV and scars }\end{array}$ & $\begin{array}{c}\text { yellow white } \\
\text { lesions ill-defined } \\
\text { in perimacular } \\
\text { area }\end{array}$ \\
\hline FA & $\begin{array}{c}\text { Optic disc } \\
\text { hyperfluorescence } \\
\text { with vascular } \\
\text { leaking }\end{array}$ & $\begin{array}{c}\text { Early } \\
\text { hypofluores- } \\
\text { cence with late } \\
\text { hyperfluores- } \\
\text { cence }\end{array}$ & $\begin{array}{c}\text { Early } \\
\text { hypofluorescence } \\
\text { with late } \\
\text { hyperfluorescence } \\
\text { old lesions are } \\
\text { hypofluorescent } \\
\end{array}$ & $\begin{array}{l}\text { Hypofluores- } \\
\text { cence with } \\
\text { hyperfluores- } \\
\text { cence on margin }\end{array}$ & $\begin{array}{l}\text { Hyperfluores- } \\
\text { cence with } \\
\text { pinpoint lesions }\end{array}$ \\
\hline OCT & $\begin{array}{c}\text { Disruption of } \\
\text { IS/OS junction, } \\
\text { tinning of } \\
\text { Sattler's layer, } \\
\text { atrophy of choroid }\end{array}$ & $\begin{array}{l}\text { Hyperreflec- } \\
\text { tivity of outer } \\
\text { layers; RPE } \\
\text { atrophy in late } \\
\text { stage }\end{array}$ & $\begin{array}{l}\text { Thickening of } \\
\text { outer retina with } \\
\text { disruption of } \\
\text { IS/OS junction } \\
\text { and with } \\
\text { increased } \\
\text { reflectivity of } \\
\text { choroid }\end{array}$ & $\begin{array}{c}\text { Focal } \\
\text { hyperreflec- } \\
\text { tivity and } \\
\text { subsequent } \\
\text { focal atrophy of } \\
\text { RPE }\end{array}$ & $\begin{array}{l}\text { Accumulation of } \\
\text { hyperreflective } \\
\text { material on RPE }\end{array}$ \\
\hline
\end{tabular}



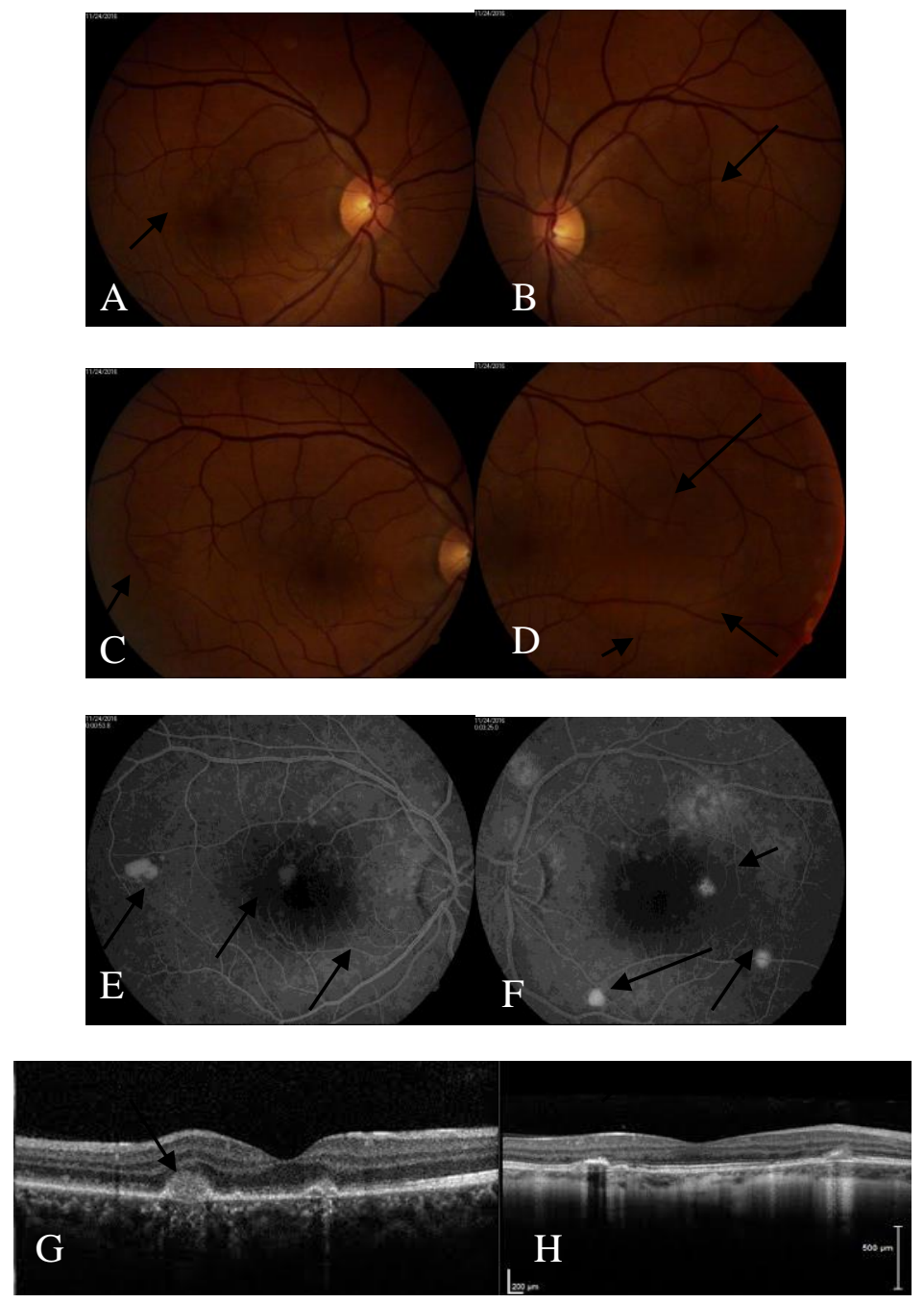

$A$ and $C$ Photofundus of the right eye

$B$ and $D$ Photofundus of the left eye

$E$ and $F$ FA of the right and left eye

$\mathrm{G}-\mathrm{OCT}$ active lesion

$\mathrm{H}$ - OCT inactive lesion

Figure1. PIC multimodal imaging

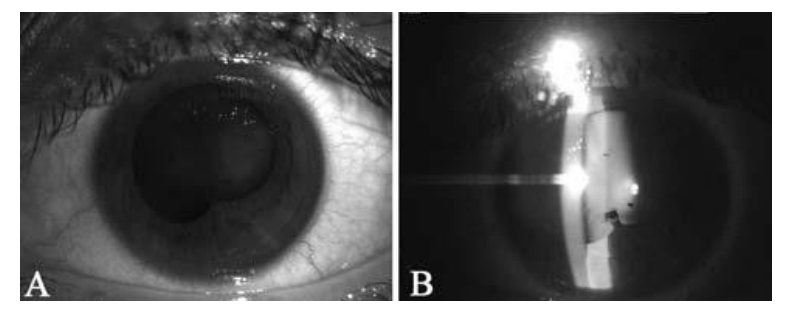

Figure 2. A and B Anterior segment in patient with SPC 

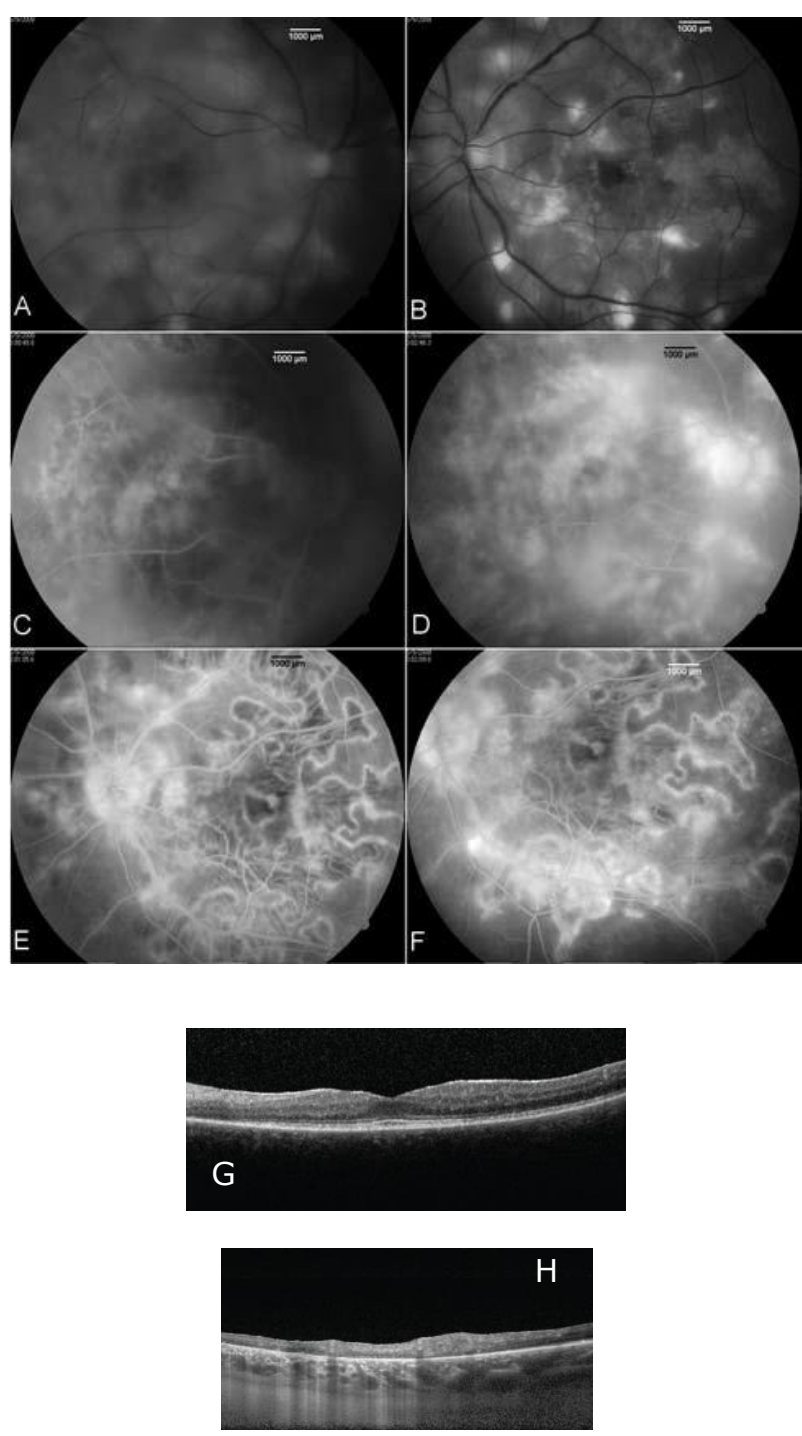

A and B Photography

$C, D, E, F-F A$

G- OCT active lesion

$\mathrm{H}$ - OCT inactive lesion

Figure 3. SPC multimodal imaging
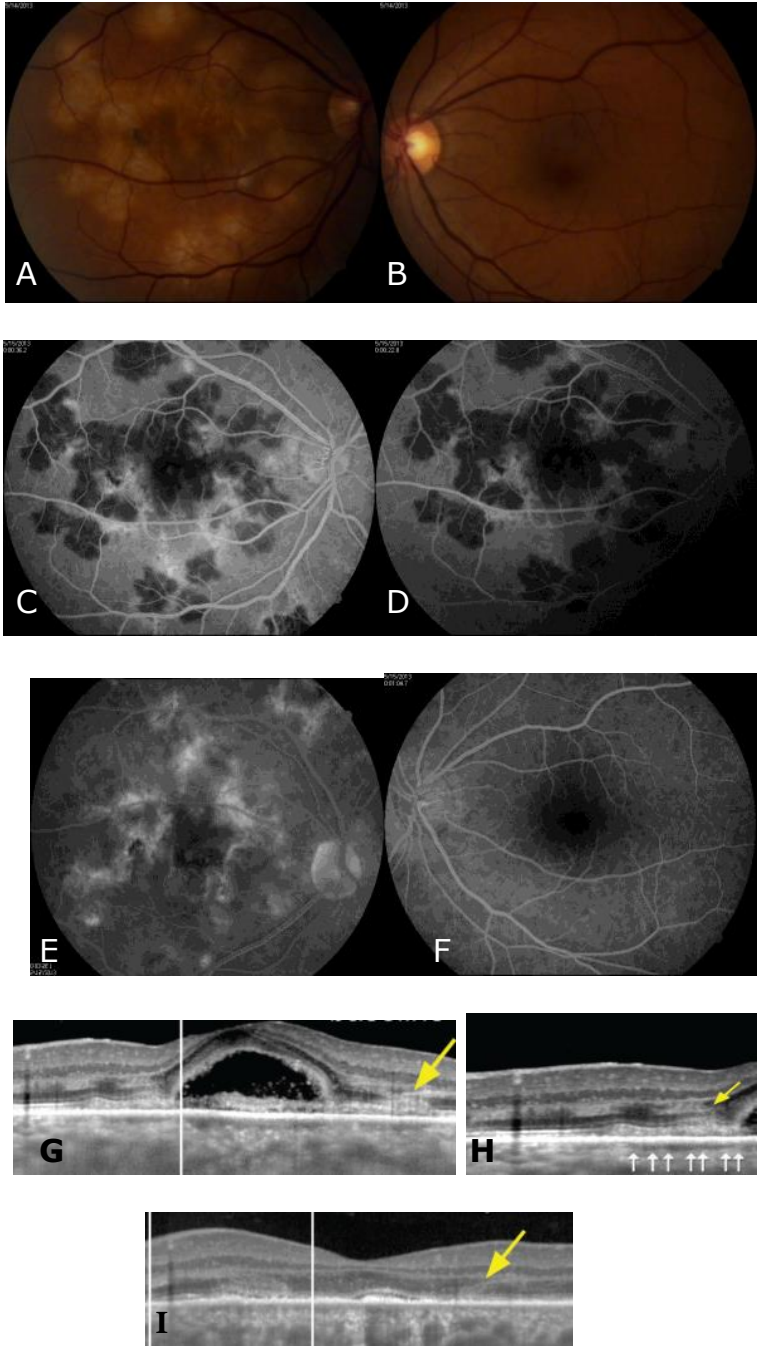

A- Color photography of the right eye $B$ - Color photography of the right eye

$C, D, E, F-F A$

$\mathrm{G}, \mathrm{H}$ - OCT active lesion

I- OCT inactive lesion

Figure 4. AMPPE multimodal imaging
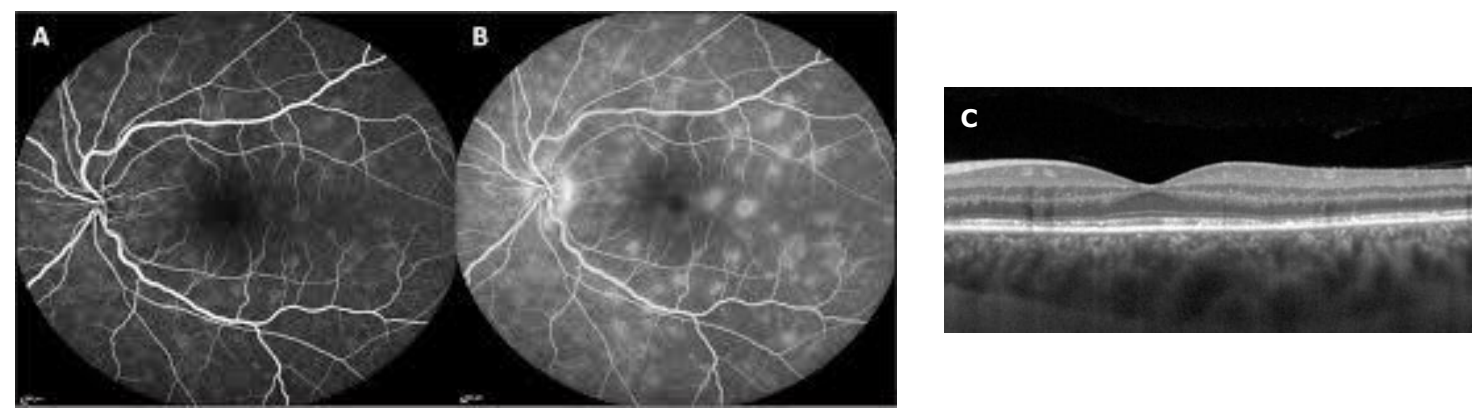

A- Photography, B- FA, C- OCT

Figure 5. MEWDS multimodal imaging 

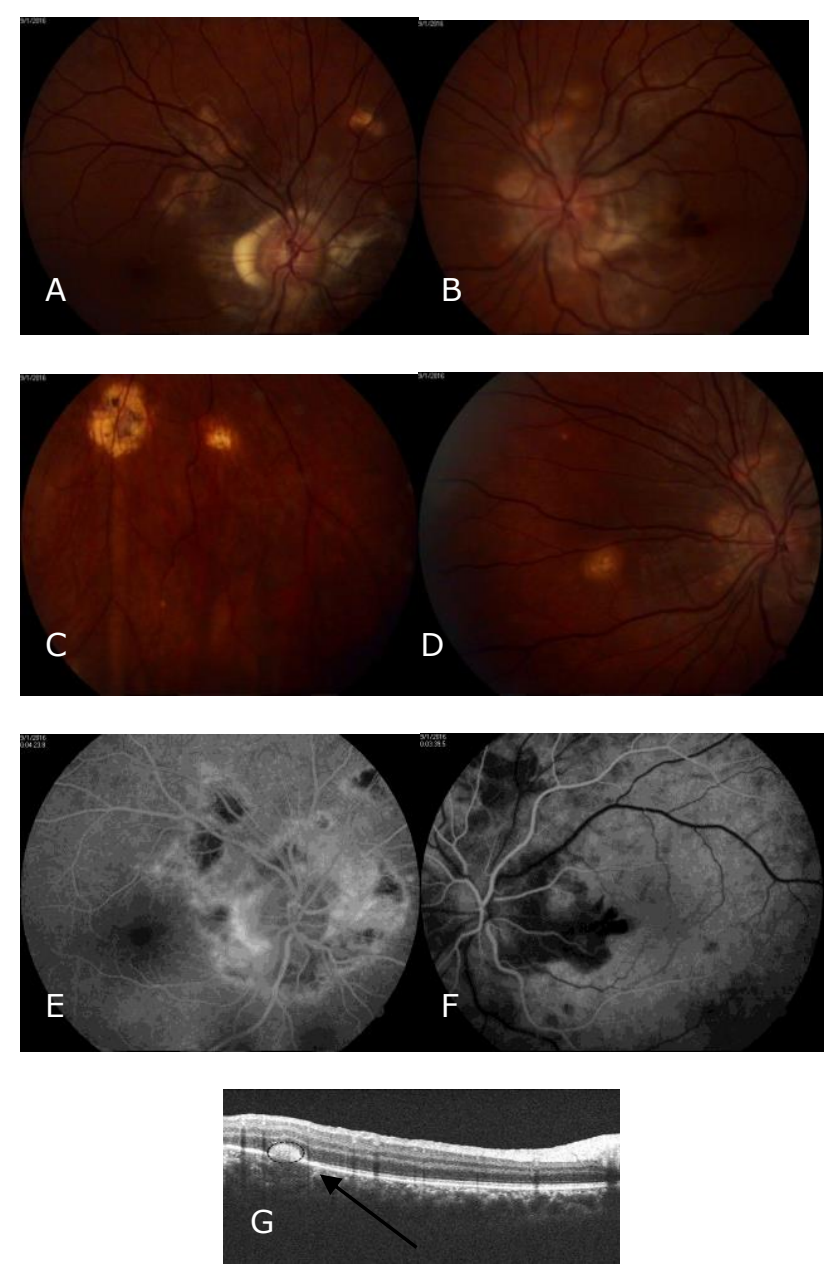

A, B, C, D- Color photography

E, F- FA and G- OCT active lesion

Figure 6. BRC multimodal imaging

Accumulation of hyperreflective material that rested on RPE, and extended through the interdigital zone, ellipsoid zone, and outer nuclear layer (ONL) was observed by OCT in patients with MEWDS (Figure 5). The abnormalities of retinal architecture restored spontaneously. During FA in these patients, multiple lesions with early hyperfluourescence in a wreath-like configuration were detected. The lesions were presented in mid retina and hyperfluorescence persisted in late phase of FA (Figure5).

During the active phase in patients with SPC, hyperreflective lesions and thickening of the outer retina were noted (Figure 6). Hyperreflective inflammatory PED, similar to PIC, was present as well (Figure 6). The reflectance of choroid was increased causing the so called waterfall effect (Figure 6). The inner and outer photoreceptor layers as well as their junction were interrupted. Active lesions on FA showed early hypofluorescence and late hyperfluorescence of the border (Figure 6). Old lesions were presented by window defect and late staining on FA (Figure 6).

\section{Discussion}

Multifocal chorioretinitis presents separate group of posterior uveitis with similar clinical findings. Multimodal imaging such as color photofundus, FA, OCT, and ultrasonography can help in diagnosis, differential diagnosis and follow-up of disease course $(10,11,12,13)$. Authors also proposed fundus autofluorescence (FAF) and angio OCT as methods of choice for diagnosis and follow-up of MPC (13).

Anterior segment inflammation was present in patients with SPC. In our patient, in the color photography, findings differed in size, color or localization of lesions (Table 1). Atrophic lesions were present in patients with BRC and SPC; pigmented lesions were present in patients with AMPPE. Similar results are present in the literature $(1,7,14,15,16)$. Retinal architecture restored spontaneously in patients with MEWDS. BRC, SPC and PIC had a chronic course. These entities need to be monitored closely in order to detect the development of choroidal neovascularization (CNV) (13). During our study, we did 
not notice CNV in patients. New imaging technic, angio OCT, is more sensitive in detection of CNV (13). Imaging technics are important in differential diagnosis of MPC for infectious uveitis as well as for primary or secondary neoplastic changes $(6,7,16)$.

Limitations of FA imaging are opacification of anterior segment intensive vitreous haze or hemorrhage in vitreous. It is an invasive method of examination, and practitioner should be cautious about patients with allergic reactions, heart, liver and kidney disease.

OCT examination is easy to perform and noninvasive method. However, some limitations of OCT examination are present. Corneal opacification, dense cataract, significant vitreous haze or hemorrhage in the eyes are limiting factors for OCT examination. Eye tracking system overcomes acquisition errors and enables a high intra-observer reproducibility allowing determination of minimal changes that may occur between successive examinations (7). Shadowing of the underlying retinal structures by hyperreflective lesions such as exudates, hemorrhages and major retinal vessels can lead to the loss of detail of underlying morphology.

\section{Conclusion}

Multimodal imaging has allowed us to better understand morphology, activity and stage of lesions. The common features of all presented cases of multifocal chorioiditis entities are: minimal lesions at the initial stage of disease, multifocal white, or white/yellow multiple lesions, during the progression of disease degeneration of retinal tissue and choroid confirmed by OCT and FA, similar clinical presentation. OCT is important in diagnosis, differential diagnosis and follow-up.

\section{Acknowledgement}

Authors declare no financial support.

\section{Conflict of Interests}

No conflict of interests

\section{Declaration of Funding Sources}

We declare no funding sources

\section{References}

1. Crawford CM, Igboeli O. A Review of the Inflammatory Chorioretinopathies: The White

2. Dot Syndromes. ISRN Inflammation 2013; 2013: 783190. [PubMed]

3. Fung AT, Pal S, Yannuzzi NA, Christos P, Cooney M, Slakter JS, et al. Multifocal choroiditis without panuveitis: clinical characteristics and progression. Retina 2014; 34(1):98-107. [PubMed] [CrossRef]

4. Tavallali A, Yannuzzi LA. Idiopathic Multifocal Choroiditis. J Ophthalmic Vis Res 2016; 11(4):429-32. [PubMed] [CrossRef]

5. Touhami S, Fardeau C, Vanier A, Zambrowski O, Steinborn R, Simon C, et al. Birdshot Retinochoroidopathy: Prognostic Factors of Long-term Visual Outcome. Am J Ophthalmol 2016; 170:190-6.

[PubMed] [CrossRef]

6. Jung JJ, Khan $S$, Mrejen $S$, Gallego-Pinazo $R$, Cunningham ET Jr, Freund KB, et al. Idiopathic multi- focal choroiditis with outer retinal or chorioretinal atrophy. Retina 2014; 34(7):1439-50.

[PubMed] [CrossRef]

7. Spaide RF, Goldberg N, Freund KB. Redefining multifocal choroiditis and panuveitis and punctate inner choroidopathy through multimodal imaging. Retina 2013; 33(7):1315-24. [PubMed] [CrossRef]

8. Raven $M L$, Ringeisen $A L$, Yonekawa $Y$, Stem MS, Faia U, Gottlieb JL. Multi-modal imaging and anatomic classification of the white dot syndromes. Int J Retina Vitreous 2017; 20;3:12.

9. Brydak-Godowska J, Gołębiewska J, Turczyńska M, Moneta-Wielgoś J, Samsel A, Borkowski PK, et al. Observation and Clinical Pattern in Patients with White Dot Syndromes: The Role of Color Photography in Monitoring Ocular Changes in Long-Term Observation. Med Sci Monit 2017; 23:1106-15.

[PubMed] [CrossRef] 
10. Teussink MM, Huis in het Veld PI, de Vries LMV, Hoyng $\mathrm{CB}$, Klevering JB, Theelen T. Multimodal imaging of the disease progression of birdshot chorioretinopathy. Acta Ophthalmol 2016; 94:815-23.

[PubMed] [CrossRef]

11. Cheng L, Chen X, Weng S, Mao L, Gong Y, Yu S, et al. Spectral-domain optical coherence tomography angiography findings in multifocal choroiditis with active lesions. Am J Ophthalmol 2016; 169:145-61.

[PubMed] [CrossRef]

12. Vance SK, Khan S, Klancnik JM, Freund KB. Characteristic spectral-domain optical coherence tomography findings of multifocal choroiditis. Retina 2011; 31(4): 717-23. [PubMed] [CrossRef]

13. Kramer M, Priel E. Fundus autofluorescence imaging in multifocal choroiditis: beyond the spots. Ocul Immunol Inflamm 2014; 22(5):349-55. [PubMed] [CrossRef]
14. Dutheil C, Korobelnik JF, Delyfer MN, Rougier MB. Optical coherence tomography angiography and choroidal neovascularization in multifocal choroiditis: A descriptive study. Eur J Ophthalmol 2018; 28(5):61421. [PubMed] [CrossRef]

15. Xerri O, Salah S, Monnet D, BrézinXerri AP. Un-treated Acute Posterior Multifocal

16. Placoid Pigment Epitheliopathy (APMPPE): a case series. BMC Ophthalmology 2018; 18:76. [PubMed] [CrossRef]

17. Cohen LM, Goldstein DA, Fawzi AA. Structure-function Relationships in Uveitic Cystoid Macular Edema: Using En Face Optical Coherence Tomography to Predict Vision. Ocul Immunol Inflamm 2016; 24(3):274-81. [PubMed] [CrossRef]

18. Onal S, Tugal-Tutkun I, Neri P, Herbort CP. Optical coherence tomography imaging in uveitis. Int Ophthalmol 2014; 34(2):401-35. [PubMed] [CrossRef] 


\title{
MULTIMODALNE TEHNIKE VIZUELNOG PRIKAZA PACIJENATA SA MULTIFOKALNIM HOROIDITISOM SA PATOLOGIJOM NA NIVOU SPOLJAŠNJE HORIO - RETINALNE BARIJERE
}

\author{
Sonja Cekić1, Predrag Jovanović1,2, Ivan Jovanović2, Gordana Stanković-Babić ${ }^{1}$, \\ Dijana Risimić3
}

1Univerzitet u Nišu, Medicinski fakultet, Klinika za očne bolesti, Niš, Srbija
Univerzitet u Nišu, Medicinski fakultet, Katedra za anatomiju, Niš,Srbija
${ }^{3}$ Univerzitet u Beogradu, Medicinski fakultet, Klinika za očne bolesti, Beograd, Srbija

Kontakt: Sonja Cekić

Bulevar Dr Zorana Đinđića 48,18000 Niš, Srbija

E-mail: sonjaziv@yahoo.com

Cilj naše studije je prikaz različitih tehnika vizuelnog prikaza bolesnika sa multifokalnim horoiditisom i to: punktiformnom unutrašnjom horoidopatijom (PIC), Birdshot horioretinopatijom (BRC), akutnom multifokalnom pigmentom plakoidnom epiteliopatijom (AMPPE), sindromom multiplih nestajućih belih tačkica (MEWDS) i serpenginoznim horoiditisom (SPC); i utvrditi njihov dijagnostički prognostički značaj.

Studija je sprovedena na Klinici za očne bolesti Kliničkog Centra u Nišu. U periodu od šest godina kod deset bolesnika postavljena je dijagnoza mulifokalnog horioretinitisa. Standardni oftalmološki pregled podrazumevao je: određivanje subjektivne vidne oštrine, pregled prednjeg segmenta biomikroskopom, aplanacionu tonometriju, indirektnu oftalmoskopiju, fotodokumentaciju, fluresceinsku angiografiju (FA), optičku koherentnu tomografiju (OCT) i pregled ultrazvukom. Sprovedeno je i standardno laboratorijsko ispitivanje, imunološko ispitivanje i sprovedena je HLA tipizacija.

Vidna oštrina bila je očuvana kod svih bolesnika osim kod pacijenta sa dijagnozom SPC. Bolest je bila bilateralna kod bolesnika sa AMPPE, SPC I PIC. Hronični tok bolesti bio je prisutan kod bolesnika sa dijagnozom SPC i PIC.

Zajedničke karakteristike kod svih bolesnika sa multifokalnim horoiditom bile su: minimalna oštećenja u početnom stadijumu bolesti, brojne beličaste ili žutobeličaste lezije, kao i to da napredovanje oboljenja dolazi od degenerativnog oštećenja tkiva. Promene su dokazane OCT i FA metodom.

OCT je značajan za diferencijalnu dijagnozu i praćenje.

Dobijeni rezultati u skladu su sa rezultatima sprovedenih studija, a različitost nalaza u pojedinim oboljenjima predmet je daljeg istraživanja.

Acta Medica Medianae 2019;58(3):85-92.

Ključne reči: horioretinitis, dijagnoza, vizuelni prikaz 